\title{
The effects of electrification on employment in rural Peru
}

\author{
Rosamaría Dasso ${ }^{1 *}$ and Fernando Fernandez ${ }^{2}$
}

\author{
*Correspondence: \\ r.dasso@cgiar.org \\ 1 International Food Policy Research \\ Institute, Markets, Trade and \\ Institutions Division, 2033 K Street \\ NW, Washington, DC 20006, USA \\ Full list of author information is \\ available at the end of the article
}

\begin{abstract}
We study the effects of a rural electrification program on employment in Peru. Taking advantage of the program's roll-out across districts over time, we adopt differences-in-differences and fixed-effects strategies to estimate the impact of electrification on labor market outcomes. Our preferred specification suggests that, among males, the program increases hours of work and diminishes the likelihood of having a second occupation. Among females, the treatment raises employment and earnings and increases the probability of working outside the agricultural sector.
\end{abstract}

JEL codes: J22; 013

Keywords: Electrification; Employment; Peru

\section{Introduction}

Access to public services and infrastructure such as water (Devoto et al. 2012; Sekhri 2014), roads (Banerjee et al. 2012), electricity (Dinkelman 2011; Rud 2012; Libscomb et al. 2013) and telecommunications (Goyal 2010; Beuermann 2011; Beuermann et al. 2012) seems to be key to generate welfare improvements in rural areas. Many governments in developing countries allocate large amounts of money to finance infrastructure projects as an attempt to boost economic development in poor areas. The growing empirical literature on this topic has documented that such public projects have positive effects on the welfare of rural households by allowing them to have access to markets, jobs and information.

In this study, we evaluate the impacts of electrification on employment in rural Peru. In 2006, only 39 percent of rural households had access to electricity. However, the Peruvian government rapidly increased electricity coverage during the last decade through the Programa de Electrificación Rural, known as PER (for its acronym in Spanish). Rural families largely depend on the labor market to meet their consumption plans, so we focus on the impacts of electrification on employment.

Electricity provision can affect labor outcomes through different channels. First, it can be thought of as a technological shock that improves household production. Second, it implies a larger time endowment because everyone can work during the night (and not only during the day). Third, it could promote the start of new businesses by allowing households to produce goods and services that require appliances. Fourth, it might increase the time spent watching TV (Olken 2009).

(c) 2015 Dasso and Fernandez; licensee Springer. This is an Open Access article distributed under the terms of the Creative Commons Attribution License (http://creativecommons.org/licenses/by/4.0), which permits unrestricted use, distribution, and reproduction in any medium, provided the original work is properly credited. 
Since the theoretical prediction of access to electricity on labor supply is ambiguous, we empirically examine the total effect of electrification on different employment outcomes in Peru. Two previous studies analyze the association between access to electricity and hours of work in Peru (Escobal 2005; Torero et al. 2007). Based on matching techniques, both papers find that households with electricity work more hours in non-farm activities than families without electricity. However, it is likely that unobservable differences remain even after controlling for observable characteristics. Using data from other developing countries, four more recent papers deal better with the fact that electricity is not randomly assigned to households.

First, Dinkelman (2011) estimates the impact of electricity provision in rural areas of South Africa during 1990-2007. She takes advantage of the roll-out of an electrification program done by ESKOM, the electricity utility. Between 1993 and 2003, about 470,000 households were electrified. Program placement was not random so the author uses community level data and relies on instrumental variables and fixed-effects strategies to uncover their parameters of interest. In particular, she uses land gradient as an instrument for program placement and then adopts a fixed-effects estimator to remove time-invariant unobservables that may jointly affect program placement and employment. Her results indicate that electrification leads to an increase in female employment in both the extensive and intensive margin and that women's wages fall while male earnings go up.

Second, Rud (2012) evaluates the link between electricity provision and industrialization in India during the period 1965-1984. To overcome endogeneity concerns, he uses the start of the Green Revolution, an agricultural technology intensification in irrigation introduced in the 1960s as a natural experiment. In particular, he predicts electricity expansion using (initial) groundwater availability in the 1960s. The author documents that an increase in electrification provision is associated with gains in manufacturing output. He also finds that places with higher access to electricity have more factories and output among small firms.

Third, Libscomb et al. (2013) analyze the effects of electrification on the Human Development Index (HDI) using county-level data from Brazil. The authors also rely on geographic characteristics to adopt an IV approach. More specifically, they simulate how the electricity grid would have evolved if its expansion had only taken into account geographic cost considerations (water flow and river gradient), ignoring demand-side considerations. Then, they use this forecast as an instrument for actual program placement. Their results indicate that electricity provision is associated with higher levels of HDI. Moreover, their analysis suggests that migration is unlikely to account for the large magnitude of development gains observed. They also estimate large, positive effects of electrification on employment, salaries, and investments in education, but not health.

Fourth, Grogan and Sadanand (2013) use several methods to analyze the association between household electricity and time use in Nicaragua. Using past population density as an instrument for current access to electricity, they find that access to electricity makes women - but not men - more likely to work outside home.

Our paper adds to this literature by using individual-level data instead of aggregate data. Also, we have detailed information on labor outcomes that allow us to identify the channels through which electrification affects employment. In the absence of an experimental design, our approach consists of using two identification strategies: 
Differences-in-Differences and Fixed-Effects. For the former, we use seven repeated cross-sections of the Peruvian household survey during the period 2006-2012. For the latter, we utilize a unique household panel data set collected between 2007 and 2010.

We document the following impacts of the program on labor outcomes. Our preferred specification suggests that men in treated areas reallocate their time devoted to work as follows: they work harder (2.5 additional hours per week) in their main occupation but are less likely to have a second job (a reduction of 6 percentage points). Among women, our estimates indicate that treatment increases earnings and hourly wages by around 30 percent. Additional evidence suggests that these gains are related to a lower probability of working in agriculture. Since male earnings are unaffected, these estimates imply that the program has reduced the gender wage gap in treated districts. These findings represent our contribution to the literature that examines the role of electricity provision on labor markets in developing countries.

The rest of the paper proceeds as follows. Section 2 describes the electrification program and our data sources. Section 3 outlines the empirical strategies. Section 4 presents our results. Section 5 offers concluding remarks.

\section{The program and data sources}

\subsection{The electrification program}

In 1993, the Peruvian Ministry of Energy and Mining launched the Rural Electrification Program (PER, for its acronym in Spanish) as an attempt to foster social and economic development in rural areas. The implementation of the program began after the enactment of the "Act of Rural Electrification". According to this Act, the main objective of PER is to provide rural families with electricity, with the support of the private sector, public institutions, and local governments.

The program placement was not random. Instead, the Ministry used the following set of variables to identify eligible districts:

- Lower index of rural electrification (percentage of households with electricity)

- Higher poverty rate (percentage of households whose consumption is below the poverty line)

- Lower proportion of the estimated subsidy per connection

- Lower cost per connection

- Higher use of renewable energy

Based on these dimensions, they defined the roll-out of the program. However, the program did not expand according to these criteria because every time new data was released (or new authorities got elected to work for the Ministry) the initial plans were changed. In fact, the Ministry divided the PER in two sub-periods: 1993-2004 and 2005-2010. The first sub-period was based on variables constructed using the population census from 1993. The second sub-period used data from three sources: census 1993, census 2005, and the country's poverty map from 2007.

By the end of 2012, 628 electrification projects had been concluded throughout rural Peru. To illustrate, we present the roll-out of the program during 2007-2010 in Figure 1. The distribution of the projects according to its type is as follows: i) 55 transmission lines with a length of 2,872 kilometers; ii) 299 rural electrical systems whose total length is 20,000 kilometers; iii) 268 hydro-power plants; iv) 4 projects that included the installation 


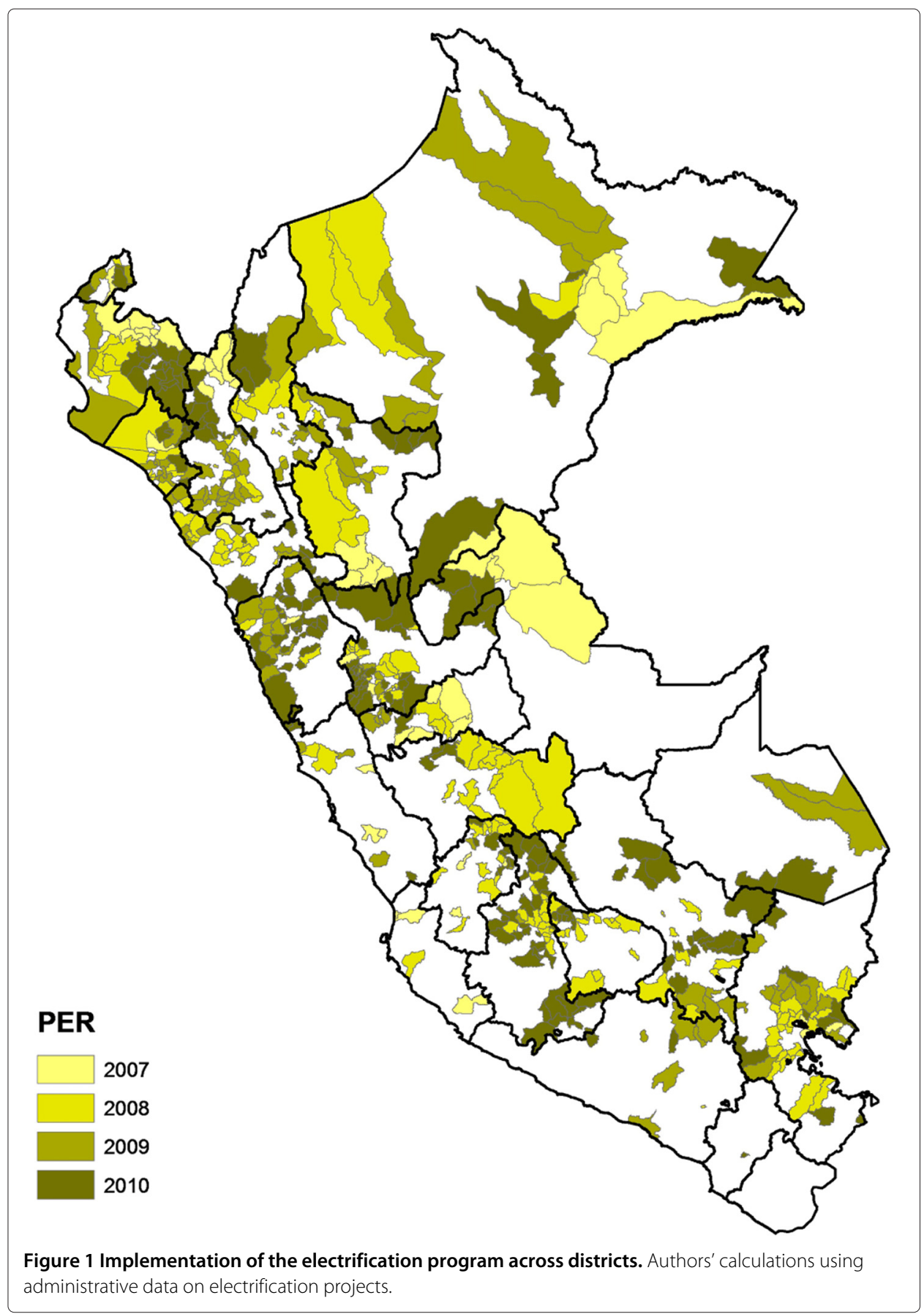

of 1,523 solar panels; and v) 2 wind-turbines. The Peruvian government has spent around US $\$ 657.5$ million on these projects. Once projects have been concluded, companies provide electricity to households upon paying for connection (and the subsequent electricity bills). To get a sense of how large these costs are, Table 1 provides average monthly spending on electricity as a fraction of total expenditures across households. It is clear from the figures that, in both control and treatment areas, spending on electricity represents only a minor fraction of total spending. 
Table 1 Average monthly expenditures on electricity as a fraction of total household expenditures

\begin{tabular}{llllllll}
\hline & $\mathbf{2 0 0 6}$ & $\mathbf{2 0 0 7}$ & $\mathbf{2 0 0 8}$ & $\mathbf{2 0 0 9}$ & $\mathbf{2 0 1 0}$ & $\mathbf{2 0 1 1}$ & $\mathbf{2 0 1 2}$ \\
\hline All districts & $3.8 \%$ & $4.8 \%$ & $4.0 \%$ & $4.1 \%$ & $3.7 \%$ & $4.2 \%$ & $6.4 \%$ \\
Treated districts & $2.8 \%$ & $4.3 \%$ & $4.2 \%$ & $4.2 \%$ & $3.4 \%$ & $3.9 \%$ & $4.2 \%$ \\
Non-treated districts & $4.3 \%$ & $5.2 \%$ & $3.8 \%$ & $4.1 \%$ & $3.9 \%$ & $4.4 \%$ & $8.6 \%$ \\
\hline
\end{tabular}

Note: We use ENAHO cross-sections from 2006 to 2012 to estimate the average monthly expenditures as a fraction of total expenditures across households, by area (treated and non-treated).

For the empirical analysis, we only use data on projects that were concluded in the period 2007-2010. We do so for two reasons. First, because of rapid economic growth and high political stability, most projects were concluded in this period (567 projects out of 628). Second, the National Office Statistics collected a unique household panel data set during these same years.

\subsection{Data sources}

Our primary data source is the Encuesta Nacional de Hogares (henceforth, ENAHO) conducted by the National Institute of Statistics on a yearly basis. This representative household survey includes rich information on labor outcomes and other individual characteristics. In the Differences-in-Differences (DD) approach, we pool repeated annual cross-sections for the period 2006-2012. In the Fixed Effects (FE) strategy, we use a unique household panel data set collected between 2007-2010, using a random sub-sample of the cross-section from 2007.

The dependent variables are taken from ENAHO's employment record (in which all individuals over 14 years old are interviewed). We construct nine labor market outcomes for the empirical analysis: i) participation; ii) employment; iii) hours of work; iv) log earnings; v) log hourly wages; vi) whether the individual has two jobs; vii) whether he is a wage-earner; viii) whether he works in agriculture; and ix) whether he is self-employed. The vector of controls used in the DD approach is taken from ENAHO's education record. It includes characteristics such as maternal language, sex, age, and education level. We also include an indicator variable for the presence of children below 5 in the household, taken from the demographics record (see the Appendix for further details).

The list of electrification projects was taken from administrative records of the Ministry of Energy and Mining. In our study period, 567 projects (out of 628) were concluded in 412 rural districts. For each electrification project, we observe the year of conclusion and the treated districts (101 projects include more than one district).

Treated districts are defined as follows. We say that a district is treated by year $t$ if at least one project had been concluded in that year or earlier. Using unique district identifiers, year of interview and year of conclusion of each project, we match both data sets. After doing so, our DD and FE samples include 246,735 and 12,964 individuals, respectively.

Figure 2 shows the evolution of electricity coverage by area (treated and non-treated). In both samples, we note that initial coverage was lower in treated areas than in control districts, which is consistent with the criteria used by the Ministry. In the DD sample (left panel), we see that treated areas experienced a rapid growth in access to electricity: coverage went from 26 percent in 2006 to 67 percent in 2012. A similar expansion in access to electricity is observed in the panel sample (right panel). 


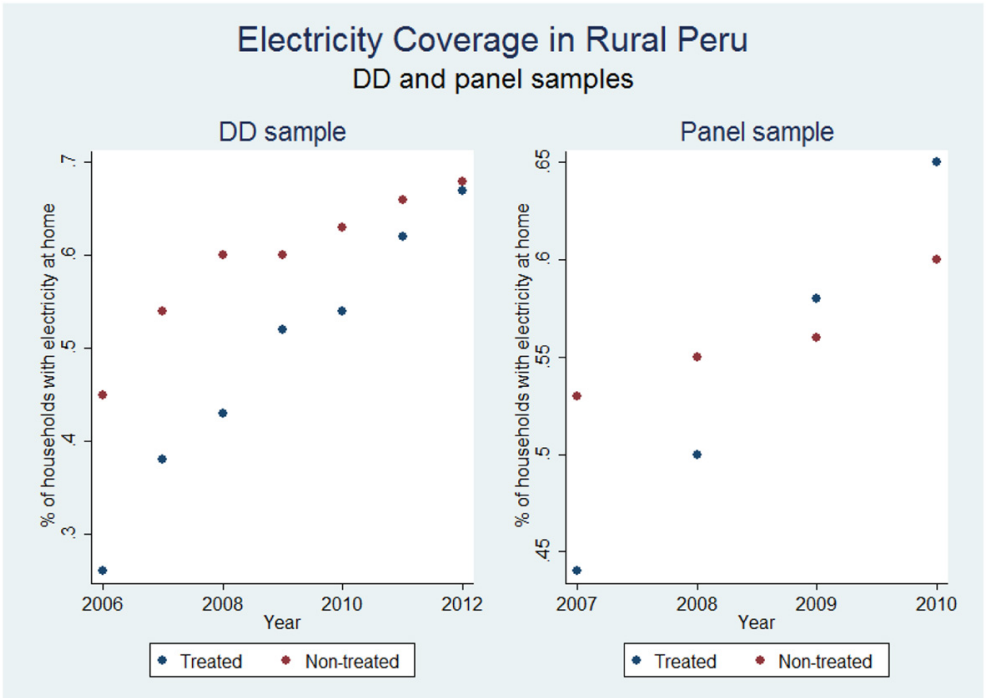

Figure 2 Electricity coverage in rural Peru. Authors' calculations using ENAHO. The DD sample includes annual cross-sections from 2006 to 2012. The Panel sample goes from 2007 to 2010.

To show that the program led to higher electricity coverage, we regress actual access to electricity at home on our treatment variable along with year fixed effects- and district (individual) fixed-effects in the DD (panel) sample. Table 2 reports the corresponding estimates for both samples. Both columns document the positive and highly significant impact of the treatment on access to electricity: coverage in treated districts is roughly 8 percentage points higher than in control areas. Taken together, these results suggest that our main independent variable is strongly correlated with actual access to electricity.

\section{Empirical analysis}

Since PER did not have an experimental design, any difference in outcomes between treated and non-treated households would be a biased estimate of the effect of the program (Angrist and Pischke 2009). To deal with unobserved confounders, we rely on two non-experimental methods to estimate the impact of PER on labor outcomes. First, we utilize repeated cross-sections and adopt a Differences-in-Differences (DD) approach.

Table 2 The Effects of the PER on access to electricity

\begin{tabular}{lll}
\hline Sample: & DD & Panel \\
& $(1)$ & $(2)$ \\
\hline PER & $0.082^{* * *}$ & $0.075^{* * *}$ \\
& $(0.017)$ & $(0.009)$ \\
Observations & & 12,969 \\
R-squared & 279,540 & 0.075 \\
N. of individuals & 0.464 & 3,980 \\
\hline
\end{tabular}

Note: Each column is a separate regression. The dependent variable is equal to 1 if the individual's household has electricity and 0 otherwise. Column (1) includes district and year fixed effects and standard errors (in parentheses) are clustered at the district level. Column (2) includes individual and year fixed effects, and standard errors (in parentheses) are clustered at the individual level.

* , ${ }^{* *}{ }^{* *}$ denote significance at the $10 \%, 5 \%, 1 \%$ level, respectively. 
Second, we use household panel data to apply a Fixed Effects (FE) estimation. In both cases, non-treated and treated households would be referred to as the control and treatment group, respectively. Each approach has its identifying assumptions and data requirements which we describe with further detail in the next subsections. Given that FE not only captures district-level unobservable characteristics but also individual-level heterogeneity, we refer to it as our preferred specification.

\subsection{Differences-in-differences (DD)}

The DD approach exploits the roll-out of the program to remove permanent differences across control and treated districts. That is, the DD estimator solves the problem of endogenous program placement under the assumption that the selection bias is additive and does not vary over time (Imbens and Wooldridge 2009).

To fix ideas, let $i=1,2, \ldots, N, j=1,2, \ldots M$, and $t=1,2, \ldots, T$ denote, individuals, districts and years, respectively. This setup lead us to estimate the following equation:

$$
y_{i j t}=\alpha_{j}+\alpha_{t}+\beta P E R_{j t}+X_{i j t}^{\prime} \gamma+\mu_{i j t},
$$

where $y_{i j t}$ is the outcome variable (participation, hours of work, and so on); $\alpha_{j}$ and $\alpha_{t}$ denote district and year fixed effects; $P E R_{j t}$ indicates that the program arrived to district $j$ in year $t ; X_{i j t}$ is a vector of individual characteristics (such as maternal language, education, and so on). The error term is denoted by $\mu_{i j t}$ and is allowed to be correlated across individuals within districts. The parameter of interest is $\beta$. We should note that we fail to identify which households are actually getting electricity at home. Therefore, we should interpret $\beta$ as the (overall) effect of providing electricity at the district level instead of measuring the impact of actually receiving it.

The staggered implementation of PER allows us to include district fixed effects which, among other things, capture geographic characteristics that are relevant to determine the cost of each project (and therefore the placement of the program). The crucial assumption to obtain consistent estimates is that, in the absence of the treatment, outcomes in treated and control districts would have had parallel trends. Figures 3 and 4 provide graphical evidence supporting this assumption. In particular, we present labor outcomes trends (participation, employment, hours of work, and earnings) estimated using ENAHO crosssections from the (pre-treatment) period 1998-2005. Two features of the data are clear. First, in both male and female samples, labor outcomes were lower in districts that were treated between 2007-2010. This evidence is consistent with the criteria used by the Ministry to define the roll-out the program. Second, in all figures, trends were parallel before the program. Thus, the parallel-trend assumption sounds plausible.

\subsection{Fixed-effects (FE)}

Rather than using repeated cross-sections, the FE approach requires following the same individuals over time. The advantage of having panel data is that we can estimate the following equation:

$$
y_{i j t}=\lambda_{i}+\lambda_{j}+\lambda_{t}+\rho P E R_{j t}+\eta_{i j t}
$$

where $y_{i j t}$ is the dependent variable, $\lambda_{j}$ and $\lambda_{t}$ denote district and year fixed effects, $P E R_{j t}$ indicates that the individual lives in a district where at least one project has been concluded by year $t$, and $\eta_{i j t}$ is the error term, which is allowed to be correlated within 


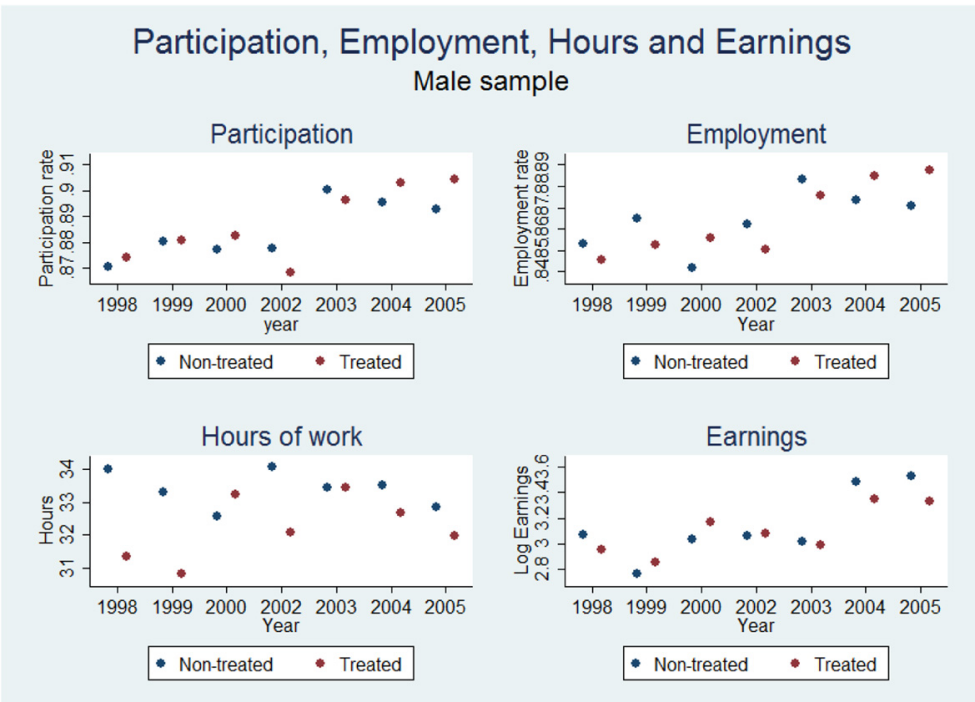

Figure 3 Males' Labor outcomes trends during the pre-treatment period (1998-2005). Male sample. Authors' calculations using ENAHO cross-sections from 1998 to 2005. Between 1998-2002, ENAHO was conducted only during the last quarter the calendar year. Only male individuals.

individuals across periods. The main difference with respect to equation (1) is the inclusion of an individual fixed effect denoted by $\lambda_{i}$, which captures unobserved individual heterogeneity. The price of doing so is that we cannot include individual controls that do not vary over time such as district/year of birth, maternal language, sex, and education. Recall that FE is our preferred specification because it is robust to the inclusion of individual fixed effects.

Participation, Employment, Hours and Earnings Female sample
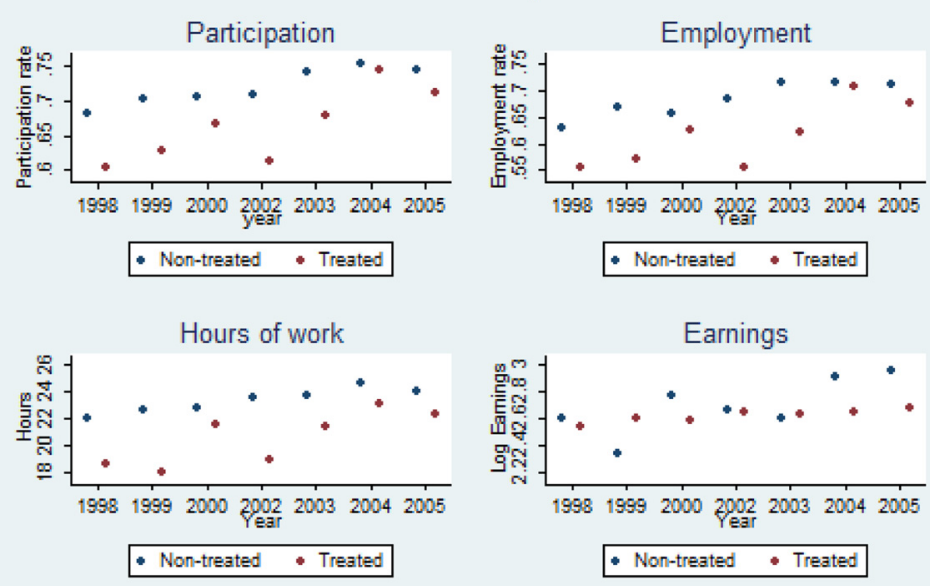

Figure 4 Females' Labor outcomes trends during the pre-treatment period (1998-2005). Female sample. Authors' calculations using ENAHO cross-sections from 1998 to 2005. Between 1998-2002, ENAHO was conducted only during the last quarter the calendar year. Only female individuals. 
The key assumption to apply an FE strategy is that unobserved confounders are timeinvariant ${ }^{1}$. Given that program placement was determined by district characteristics that can be seen as time-invariant, the identifying assumption of the FE approach seems to be reasonable.

\section{Results}

\subsection{DD Results}

We estimate equation (1) for each of our nine outcome variables, splitting the sample by gender (following Dinkelman 2011, Grogan and Sadan 2013) in order to allow for potentially different responses to electrification.

Table 3 shows our estimates of $\beta$ from equation (1), the coefficient of interest, for male individuals. In Panel A (top half of the table), we find that most point estimates are small and statistically insignificant. The only statistically significant estimate - see column $6-$ suggests that the program reduces by 1.3 percentage points the probability of having two jobs.

In Panel B, we exclude migrants from the analysis. We do so because the treatment may, for instance, induce people to move from non-treated areas to treated districts, and this systematic migration would bias our estimates. The estimated effects with this restricted sample are very similar to those with all male individuals. This similarity may indicate that migration should not be seen as a threat to the validity of our strategy.

In Table 4, we report the estimated effects of the program on female labor outcomes. Our results indicate that electricity provision increases employment and hours of work among females - columns 2 and 3 - and these estimates are fairly similar across samples (Panel A and B). Though our reduced-form approach does not allow us to distinguish demand shifts from supply shifts, the fact that wages remain constant despite increases in employment, suggests that both curves are reacting to the program.

\subsection{FE Results}

In this subsection, we report the estimates of $\rho$ from equation (2), controlling for unobserved individual heterogeneity. In Table 5, we present the point estimates for the male sample. The program has statistically significant impacts on hours of work, the likelihood of having two jobs and the probability of working in agriculture. The coefficient in column 3 suggests that providing electricity increases males' weekly hours of work. A negative effect on the probability of having two jobs is shown in column 6: treated male individuals are 6 percentage points less likely to have two jobs than men in the control group. This negative effect is larger than the point estimate from the DD specification. Finally, the point estimate in column 8 reveals that the program increases the probability of working in agriculture by 5 percentage points. Overall, the FE estimates are larger in absolute terms than the DD estimates, and this pattern may indicate that omitting unobserved individual heterogeneity (e.g., preferences for leisure) would bias DD estimates toward zero (and statistically insignificant effects).

In Table 6, we show the effects of electrification on female labor market outcomes. We notice interesting differences with respect to men. First, employment rates go up by 3.5 percentage points in treated districts. This effect is larger than the corresponding DD 
Table 3 Differences-in-differences estimates (DD) only men

\begin{tabular}{|c|c|c|c|c|c|c|c|c|c|}
\hline Dependent & (1) & (2) & (3) & (4) & (5) & (6) & (7) & (8) & (9) \\
\hline variable: & Participation & Employment & $\begin{array}{l}\text { Hours } \\
\text { of work }\end{array}$ & $\begin{array}{l}\text { Log } \\
\text { earnings }\end{array}$ & $\begin{array}{l}\text { Log hourly } \\
\text { wage }\end{array}$ & $\begin{array}{l}\text { Has } \\
\text { two jobs }\end{array}$ & Wage earner & $\begin{array}{l}\text { Works in } \\
\text { agriculture }\end{array}$ & Self-employed \\
\hline \multicolumn{10}{|c|}{ Panel A: All men } \\
\hline \multirow[t]{2}{*}{ PER } & -0.002 & 0.002 & 0.301 & 0.029 & 0.015 & $-0.013^{* *}$ & -0.002 & -0.001 & -0.000 \\
\hline & $(0.004)$ & $(0.005)$ & $(0.265)$ & $(0.031)$ & $(0.029)$ & $(0.006)$ & $(0.006)$ & $(0.007)$ & $(0.005)$ \\
\hline Observations & 125,098 & 125,098 & 125,098 & 49,346 & 47,721 & 125,098 & 92,766 & 125,098 & 125,098 \\
\hline R-squared & 0.065 & 0.491 & 0.331 & 0.335 & 0.306 & 0.097 & 0.220 & 0.331 & 0.462 \\
\hline \multicolumn{10}{|c|}{ Panel B: Excluding migrants } \\
\hline \multirow[t]{2}{*}{ PER } & 0.003 & 0.002 & 0.260 & 0.015 & -0.000 & $-0.015^{* *}$ & 0.001 & 0.000 & 0.003 \\
\hline & $(0.004)$ & $(0.006)$ & $(0.303)$ & $(0.038)$ & $(0.036)$ & $(0.007)$ & $(0.006)$ & $(0.007)$ & $(0.005)$ \\
\hline Observations & 91,064 & 91,064 & 91,064 & 32,579 & 31,475 & 91,064 & 68,841 & 91,064 & 91,064 \\
\hline R-squared & 0.080 & 0.506 & 0.345 & 0.312 & 0.301 & 0.111 & 0.195 & 0.350 & 0.502 \\
\hline
\end{tabular}

Note: Standard errors clustered at the district level are shown in parentheses. Each coefficient comes from a separate regression. All dependent variables are binary except for hours, log (weekly) earnings, and hourly wages. Individuals who do not work have zero (weekly) hours of work. Earnings and wages are only computed for those with positive values of income. PER is equal to one after the program arrives to a district, and zero otherwise. All regressions control for presence of children below 5 in the household, individuals' maternal language, age, and education, and district and year fixed effects. Panel A includes all men, and Panel B excludes migrants. Migrants are defined as those who, by the time of the survey, live in a district different from their district of birth.

${ }^{*},{ }^{* *},{ }^{* * *}$ denote significance at the $10 \%, 5 \%, 1 \%$ level, respectively. 
Table 4 Differences-in-differences estimates (DD) only women

\begin{tabular}{|c|c|c|c|c|c|c|c|c|c|}
\hline Dependent & (1) & (2) & (3) & (4) & (5) & (6) & (7) & (8) & (9) \\
\hline variable: & Participation & Employment & $\begin{array}{l}\text { Hours } \\
\text { of work }\end{array}$ & $\begin{array}{l}\text { Log } \\
\text { earnings }\end{array}$ & $\begin{array}{l}\text { Log hourly } \\
\text { wage }\end{array}$ & $\begin{array}{l}\text { Has } \\
\text { two jobs }\end{array}$ & Wage earner & $\begin{array}{l}\text { Works in } \\
\text { agriculture }\end{array}$ & Self-employed \\
\hline \multicolumn{10}{|c|}{ Panel A: All women } \\
\hline \multirow[t]{2}{*}{ PER } & 0.005 & $0.013^{* *}$ & $0.671^{* *}$ & 0.069 & 0.032 & 0.003 & 0.003 & -0.000 & 0.007 \\
\hline & $(0.006)$ & $(0.006)$ & $(0.272)$ & $(0.049)$ & $(0.046)$ & $(0.005)$ & $(0.003)$ & $(0.007)$ & $(0.005)$ \\
\hline Observations & 121,637 & 121,637 & 121,637 & 24,233 & 23,746 & 121,637 & 104,830 & 121,637 & 121,637 \\
\hline R-squared & 0.108 & 0.310 & 0.216 & 0.321 & 0.275 & 0.072 & 0.124 & 0.263 & 0.178 \\
\hline \multicolumn{10}{|c|}{ Panel B: Excluding migrants } \\
\hline \multirow[t]{2}{*}{ PER } & 0.005 & $0.015^{* *}$ & $0.581^{* *}$ & 0.065 & 0.062 & -0.001 & 0.003 & 0.003 & 0.002 \\
\hline & $(0.006)$ & $(0.007)$ & $(0.282)$ & $(0.059)$ & $(0.056)$ & $(0.006)$ & $(0.004)$ & $(0.007)$ & $(0.006)$ \\
\hline Observations & 89,347 & 89,347 & 89,347 & 16,350 & 16,030 & 89,347 & 77,782 & 89,347 & 89,347 \\
\hline R-squared & 0.120 & 0.342 & 0.244 & 0.322 & 0.290 & 0.081 & 0.113 & 0.278 & 0.197 \\
\hline
\end{tabular}

Note: Standard errors clustered at the district level are shown in parentheses. Each coefficient comes from a separate regression. All dependent variables are binary except for hours, log (weekly) earnings, and hourly wages. Individuals who do not work have zero (weekly) hours of work. Earnings and wages are only computed for those with positive values of income. PER is equal to one after the program arrives to a district, and zero otherwise. All regressions control for presence of children below 5 in the household, individuals' maternal language, age, and education, and district and year fixed effects. Panel A includes all women, and Panel B excludes migrants. Migrants are defined as those who, by the time of the survey, live in a district different from their district of birth.

$*{ }^{* * *},{ }^{* * *}$ denote significance at the $10 \%, 5 \%, 1 \%$ level, respectively. 


\section{Table 5 Panel data estimates (FE) only men}

\begin{tabular}{|c|c|c|c|c|c|c|c|c|c|}
\hline $\begin{array}{l}\text { Dependent } \\
\text { variable: }\end{array}$ & $\begin{array}{l}\text { (1) } \\
\text { Participation }\end{array}$ & $\begin{array}{l}\text { (2) } \\
\text { Employment }\end{array}$ & $\begin{array}{l}\text { (3) } \\
\text { Hours } \\
\text { of work }\end{array}$ & $\begin{array}{l}\text { (4) } \\
\text { Log } \\
\text { earnings }\end{array}$ & $\begin{array}{l}(5) \\
\text { Log hourly } \\
\text { wage }\end{array}$ & $\begin{array}{l}\text { (6) } \\
\text { Has } \\
\text { two jobs }\end{array}$ & $\begin{array}{l}\text { (7) } \\
\text { Wage earner }\end{array}$ & $\begin{array}{l}(8) \\
\text { Works in } \\
\text { agriculture }\end{array}$ & $\begin{array}{l}\text { (9) } \\
\text { Self-employed }\end{array}$ \\
\hline \multirow[t]{2}{*}{ PER } & -0.007 & 0.005 & $2.615^{* * *}$ & -0.075 & -0.090 & $-0.059^{* * *}$ & -0.02 & $0.052^{* * *}$ & 0.017 \\
\hline & $(0.013)$ & $(0.013)$ & $(0.885)$ & $(0.074)$ & $(0.081)$ & $(0.020)$ & $(0.017)$ & $(0.019)$ & $(0.014)$ \\
\hline Observations & 6,668 & 6,668 & 6,668 & 3,572 & 3,438 & 6,668 & 6,668 & 6,668 & 6,668 \\
\hline R-squared & 0.0007 & 0.0018 & 0.0036 & 0.0229 & 0.0353 & 0.0043 & 0.0023 & 0.0046 & 0.0006 \\
\hline N. of individuals & 2,052 & 2,052 & 2,052 & 1,410 & 1,402 & 2,052 & 2,052 & 2,052 & 2,052 \\
\hline
\end{tabular}

Note: Standard errors clustered at the individual level are shown in parentheses. Each column is a separate regression. All dependent variables are binary except for hours, log (weekly) earnings, and hourly wages. Individuals who do not work have zero (weekly) hours of work. Earnings and wages are only computed for those with positive values of income. All regressions control for year fixed effects. PER is equal to one after the program arrives to

a district, and zero otherwise. In this table, we restrict the sample to only men. 


\section{Table 6 Panel data estimates (FE) only women}

\begin{tabular}{|c|c|c|c|c|c|c|c|c|c|}
\hline $\begin{array}{l}\text { Dependent } \\
\text { variable: }\end{array}$ & $\begin{array}{l}\text { (1) } \\
\text { Participation }\end{array}$ & $\begin{array}{l}\text { (2) } \\
\text { Employment }\end{array}$ & $\begin{array}{l}\text { (3) } \\
\text { Hours } \\
\text { of work }\end{array}$ & $\begin{array}{l}\text { (4) } \\
\text { Log } \\
\text { earnings }\end{array}$ & $\begin{array}{l}\text { (5) } \\
\text { Log hourly } \\
\text { wage }\end{array}$ & $\begin{array}{l}\text { (6) } \\
\text { Has } \\
\text { two jobs }\end{array}$ & $\begin{array}{l}\text { (7) } \\
\text { Wage earner }\end{array}$ & $\begin{array}{l}(8) \\
\text { Works in } \\
\text { agriculture }\end{array}$ & $\begin{array}{l}\text { (9) } \\
\text { Self-employed }\end{array}$ \\
\hline PER & $\begin{array}{l}0.028 \\
(0.018)\end{array}$ & $\begin{array}{l}0.036^{*} \\
(0.018)\end{array}$ & $\begin{array}{l}0.869 \\
(0.850)\end{array}$ & $\begin{array}{l}0.360^{* *} \\
(0.142)\end{array}$ & $\begin{array}{l}0.358^{* *} \\
(0.143)\end{array}$ & $\begin{array}{l}0.001 \\
(0.016)\end{array}$ & $\begin{array}{l}0.014 \\
(0.013)\end{array}$ & $\begin{array}{l}-0.039^{*} \\
(0.020)\end{array}$ & $\begin{array}{l}0.046^{* * *} \\
(0.017)\end{array}$ \\
\hline Observations & 6,296 & 6,296 & 6,296 & 1,776 & 1,746 & 6,296 & 6,296 & 6,296 & 6,296 \\
\hline R-squared & 0.0016 & 0.0014 & 0.0012 & 0.0363 & 0.0513 & 0.0035 & 0.0018 & 0.0017 & 0.0024 \\
\hline N. of individuals & 1,938 & 1,938 & 1,938 & 883 & 876 & 1,938 & 1,938 & 1,938 & 1,938 \\
\hline
\end{tabular}

Note: Standard errors clustered at the individual level are shown in parentheses. Each column is a separate regression. All dependent variables are binary except for hours, log (weekly) earnings, and hourly wages. Individuals who do not work have zero (weekly) hours of work. Earnings and wages are only computed for those with positive values of income. All regressions control for year fixed effects. PER is equal to one after the program arrives to a district, and zero otherwise. In this table, we restrict the sample to only women.

$*$ ***,*** denote significance at the $10 \%, 5 \%, 1 \%$ level, respectively. 
estimate. Second, providing electricity increases earnings and hourly wages by around 35 percent. Taken together, these two effects - more employment and higher wages - are consistent with labor demand increasing more than labor supply. Third, the treatment diminishes the likelihood of working in agriculture by almost 4 percentage points (which is consistent with the findings of Escobal (2005) and Torero et al. (2007)). Fourth, women in treated areas are more likely to be self-employed than their counterparts in the control group. The differences between these figures and the DD results may suggest that controlling for individual fixed effects is relevant to obtain consistent estimates of the program effects.

\section{Concluding remarks}

Governments in developing countries devote a significant share of their resources to invest in public infrastructure. In fact, providing access to basic services such as water sanitation, electricity, and telecommunications is one of the top priorities in their policy agendas.

In this paper, we examine the labor market consequences of providing electrification to rural households using individual-level data from Peru. To deal with the endogenous placement of the electrification program, we adopt differences-in-differences (DD) and fixed-effects (FE) strategies. We therefore assume that unobserved confounders are timeinvariant at the district and individual level, respectively.

The DD estimates indicate that the program only has modest effects on labor outcomes: males seem to be less likely to have a second job, whereas females are more likely to be employed and have higher hours of work. Our FE estimates suggest that, among males, the treatment increases hours of work and decreases the likelihood of having more than one job. One potential explanation for this result is that the electrification program raises the benefits of specialization and therefore makes it less attractive to have a second occupation. In other words, electricity increases available time to work, and economies of scale increase the payoff of focusing on one occupation instead of having two. Among women, we document that employment and earnings are higher in treated areas than in control districts. Interestingly, the program also reduces the probability of working in the agricultural sector. Taken together, these pieces of evidence imply that the program has reduced the gender wage gap among beneficiaries.

Let us recall two limitations of our empirical analysis. First, the validity of our strategies rests on the assumption that selection bias takes the form of unobserved time-invariant characteristics. Second, our reduced-form estimates do not allow us to distinguish the relative importance of demand-supply shifts. The increase in both female employment and wages, however, may reflect that electrification increases labor demand more than labor supply.

Future work should look at the impact of electrification on educational outcomes. Access to electricity could be thought of as shock to school quality, which, in turn, may affect the demand for education. Also, electrification could affect health outcomes through better equipment at health centers or less demand for indoor polluting technologies (e.g., replacing wood/candles for electrical appliances/light-bulbs). Further research on such outcomes would be important to understand the overall effect of electrification on the lives of the rural poor. 


\section{Endnote}

${ }^{1}$ We distinguish the individual fixed effect from the district fixed effect only to illustrate the main difference with respect to the DD approach. However, in practice, they are not distinguishable because individuals in our panel do not migrate. Therefore, the district of residence is captured in the individual fixed effect.

\section{Appendix}

- Dependent variables:

- Participation: equal to 1 if the individual is in the labor force, and equal to 0 otherwise

- Employed: equal to 1 if the individual is in employed, and equal to 0 otherwise

- Hours of work: Equal to the hours of work in the week previous to the interview. It is zero for those who do not work.

- Log Earnings: weekly earnings are computed only for those who reported positive values of income (dependent and independent workers). In-kind payments are ignored.

- Log hourly wages: only computed for those who reported positive values of income and non-zero hours of work.

- Has 2 jobs: equal to 1 if the individual has two jobs, and equal to 0 otherwise

- Wage-Earner: equal to 1 if the individual is a wage-earner, and equal to 0 otherwise

- Agriculture: equal to 1 if the individual works in agriculture, and equal to 0 otherwise

- Self-employed: equal to 1 if the individual is self-employed, and equal to 0 otherwise

- Control variables included in the DD specifications:

- Children: equal to 1 if there are children below 5 in the household, and 0 otherwise

- Maternal language: equal to 1 if the individual speaks Quechua, and 0 otherwise

- Sex: equal to 1 if the individual is male, and 0 otherwise

- Age: age of the individual at the year of interview (measured in years)

- Educational level dummies (no education, incomplete primary, complete primary, incomplete secondary, and so on)

- District and year fixed effects

\section{Abbreviations}

PER: Rural Electrification Program; ENAHO: Encuesta Nacional de Hogares (Peruvian National Household Survey); DD: Differences-in-Differences; FE: Fixed Effects.

\section{Competing interests}

The IZA Journal of Labor \& Development is committed to the IZA Guiding Principles of Research Integrity. The authors declare that they have observed these principles.

\section{Acknowledgments}

This paper updates and supersedes a previous version available as CEDLAS Working Paper N. 150, Oct. 2013. We are indebted to Leonardo Gasparini for his invaluable guidance and support. We also thank David Lam (the editor), an anonymous referee, Manuel Hernandez and Hugo Ñopo for very helpful comments on previous drafts. We gratefully acknowledge financial support from the III Contest of Essays on Labor and Social Issues in Latin America - 2013, jointly organized by CEDLAS (UNLP-Argentina) and IDRC (Canada).

Responsible editor: David lam 


\section{Author details}

${ }^{1}$ International Food Policy Research Institute, Markets, Trade and Institutions Division, 2033 K Street NW, Washington, DC 20006, USA. ${ }^{2}$ Universitat Pompeu Fabra, Department of Economics and Business, Ramon Trias Fargas 25-27, Barcelona 08005, Spain

Received: 1 November 2014 Accepted: 4 March 2015

Published online: 15 May 2015

\section{References}

Angrist J, Pischke JS (2009) Mostly harmless econometrics, an empiricist's Companion. Princeton University Press, Princeton, New Jersey

Banerjee A, Duflo E, Quian N (2012) On the Road: Access to Transportation Infrastructure and Economic Growth in China"; National Bureau of Economic Research, Working Paper N. 17897. Cambridge Massachusetts, March 2012

Beurmann D (2011) Telecommunication Technologies, Agricultural Profitability and Child Labor in Rural Peru"; Central Bank of Peru, Working Paper Series, 2011-02. Lima, 2011

Beurmann D, McKelvey C, Sotelo C (2012) The Effects of Mobile Phone Infrastructure: Evidence from Rural Peru"; Central Bank of Peru. Working Paper Series, 2012-12. Lima, 2012

Devoto F, Duflo E, Dupas P, Pariente W, Pons V (2012) Happiness on tap: piped water Adoption in Urban Morocco. Am Econ J : Econ Policy 4:68-99

Dinkelman T (2011) The effects of rural electrification on employment: evidence from South Africa. Am Econ Rev 101:3078-3108

Escobal J (2005) The role of public infrastructure in market development in rural Peru. PhD Thesis, Wageningen University, The Netherlands

Goyal A (2010) Information, Direct Access to Farmers, and Rural Market performance in Central India. Am Econ J: Appl Econ 2:22-45

Grogan L, Sadanand A (2013) Rural electrification and employment in poor countries: evidence from Nicaragua. World Dev Elsevier 43:252-265

Imbens GW, Wooldridge JM (2009) Recent developments in the Econometrics of program evaluation. J Econ Lit 47(1):5-86 Libscomb M, Mobarak AM, Barham T (2013) Development Effects of Electrification: Evidence from Topographic Placement of Hydropower Plants in Brazil. Am Econ J: Appl Econ 5:200-231

Olken B (2009) Do television and radio destroy social capital? Evidence from Indonesian villages. Am Econ J: Appl Econ $1: 1-33$

Rud JP (2012) Electricity provision and industrial development: evidence from India. J Dev Econ 97:352-367

Sekhri S (2014) Wells, water, and welfare: the impact of access to groundwater on rural poverty and conflict. Am Econ J: Appl Econ 6:76-102

Torero M, Álcazar L, Nakasone E (2007) Provision of Public Services and Welfare of the Poor: Learning from an Incomplete 396 Electricity Privatization Process in Rural Peru "; IDB Working Paper N. 221, Washington DC, August 2007

\section{Submit your manuscript to a SpringerOpen ${ }^{\odot}$ journal and benefit from:}

- Convenient online submission

- Rigorous peer review

- Immediate publication on acceptance

Open access: articles freely available online

- High visibility within the field

Retaining the copyright to your article

Submit your next manuscript at $\boldsymbol{\triangleright}$ springeropen.com 